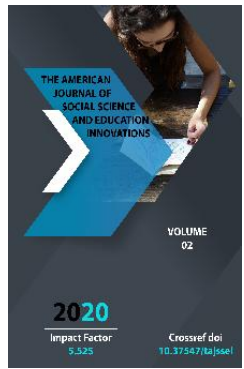

Journal Website: http://usajournalshub.c om/index,php/tajssei

Copyright: Original content from this work may be used under the terms of the creative commons attributes 4.0 licence.

\section{The Dilemma Of International Humanitarian Law: What And How It Protects}

\author{
Zhema Shishi PhD \\ Department of History and Diplomatic Studies, Federal University Wukari \\ P.M.B 1020 Wukari, Taraba State-Nigeria \\ Ochoga Edwin Ochoga \\ Department of Political Science, Federal University Lokoja Lokoja, Kogi State-Nigeria
}

\title{
ABSTRACT
}

Basically the International Humanitarian Law regime is to prevent armed conflicts and war crime, considering the catastrophic effects of wars generally. This laudable objective clearly underscored the kind of optimism most states expressed on this noble cause. In the contrary, a study of International Humanitarian Law regime over the years has left scholars more critical. This has led to divergent views about who it protects and how. While some studies questioned its evolution to be Eurocentric, some others faulted it to be unviable, non-coercive and unenforceable. This paper constitutes a scholarship on these studies and it contends that, the international humanitarian law is a branch of public international law that deals with humanitarian interventions in wartime and war crimes. The legal framework of the international humanitarian law is rooted in the Geneva Conventions of 1949. The missing link is that, the critics of the international humanitarian law based their argument on the operations of the judicial organ of the international humanitarian law, the International Criminal Court. The critics had seen the Court as a coercive tool in the hands of the western countries to witch-hunt African leaders. However, the operations of the Court should not be used as a premise to diminish the legality of the law to protect its legal personality as provided for in the Conventions. And it does not in any way invalidate the international humanitarian law of being law. This is the angle that this paper stands differently from the previous studies.

\section{KEYWORDS}

International humanitarian law, international law, Crime and Court. 


\section{INTRODUCTION}

International humanitarian law as a branch of international law started as an idea which was very simple but compelling. This idea stems from the reality of human nature and character throughout its existence. Violent conflict or war, despite its devastating consequences, has been one of the means through which relationship has been conducted. It thus became imperative to concretize this idea because some things are not permitted even in wartime. There are limits to the violence of man. Using this idea as a starting point, international humanitarian law sets forth a number of rules aimed at protecting certain categories of people who are not or are no longer taking part in the hostilities and restricting the means and methods of warfare. Previous studies on international humanitarian law mainly focused on its tenets, scope, sources, legal personalities and enforceability. Even the studies that discussed its development focused on the stages of its evaluation to the present legal regime of International Criminal Court (ICC). None of the studies advance the notion of international humanitarian law as a practical idea and as a universal idea. International humanitarian law as a practical idea intends to provoke the intellectual curiosity of students and scholars of international law to have a rethink of the origins and development of the international humanitarian law. Consequently, humanitarian law does not call into question the lawfulness off war; rather it aims first and foremost to limit the superfluous suffering that war can cause. In other words, war may now be "outlawed", but it continues to be waged in countless places around the world and to take far too high a toll.

The second is the notion of a universal idea. This implies that international humanitarian law started as a universal idea because many cultures have sought to limit the suffering that war can cause. This notion suggests that the emergence of international humanitarian law is to simply express this idea in legal terms so as to make respect for the human being in wartime as an international obligation. This conceptualization informs a position how an idea based on custom and culture calumniated into a universal idea and subsequently international law binding all States and nonstate actors in wartime.

In as much as scholars have divergent views about the origins of the international humanitarian law, its efficacy is by no means exonerated from the debate. Studies have shown that international humanitarian law is narrowed minded and an overzealous aspect of public international law that does not have the coerciveness to enforce its rules. These scholars reduced international humanitarian law to an instrument in the hands of the developed countries of the north to oppress their perceived enemies in countries of the south. In other words, this school of thought sees international humanitarian as a willing tool in the hand of the countries of the west. This conceptual impression has continued to dominate international law literature particularly in Africa. This cynical notion questions the realistic and coerciveness of the principles of the international humanitarian law. Whereas the spirit of the international humanitarian law is to deter armed conflict against human right abuse by statesmen.

This intellectual position of the scholars that expressed pessimistic views about international humanitarian law indicted the spirit and the provisions of the law. But the international humanitarian legal regime is meant to prevent war crime in an event of international conflicts and internal conflict. However, the pessimistic notion about its 
protective efficacy brings these questions to mind: how does international humanitarian law deal with international conflicts and internal conflict? And what does international humanitarian law stands for, as to who and how to protect? This form the problem in which the paper will interrogate.

\section{Conceptual Footings: International humanitarian law and the United Nations Charter: The nexus}

So many scholars have defined international humanitarian law. International humanitarian law and human rights are two separate branches of international law with a common purpose. International humanitarian law, which is also known as "the law of war" or "the law of armed conflict", does not aim to determine whether a State does or does not have the right to resort to armed force. That question is governed by a major but separate branch of international public law within the framework of the United Nations Charter. International humanitarian law stems from the codes and rules of religions and cultures around the world. International humanitarian law applies in situations of international or non-international armed conflict. Human rights law establishes rules for the harmonious development of the individual in society. The main purpose of both, however, is to safeguard human dignity in all circumstances.

Deductively In short, the key message of international humanitarian law is: (a) do not attack people who do not or no longer take part in hostilities; and (b) do not use weapons that make no distinction between combatants and civilians, or weapons and methods of warfare which cause unnecessary suffering and/or damages. This conceptualization applies once a conflict has broken out and is equally binding on all the parties, no matter which one started the fighting. This takes us to what does the United Nations Charter have to say?

The United Nations Charter, which was adopted in 1945, stipulates that the member- states are to refrain from the threat or use of force against other States, thus establishing that war no longer constitutes an acceptable means of settling disputes between States. The Charter nevertheless makes exceptions to this rule, granting the States the right to defend themselves, individually or collectively, against attacks that threaten their independence or their territory. Moreover, Chapter VII authorises memberstates to use force in the framework of collective action to maintain international peace and security, and the prohibition to resort to force does not apply to internal armed conflicts. The entrenchment of the international humanitarian law as an aspect of public international law became imperative as the 2oth century was the deadliest of all. With each passing century, war has taken a higher toll in human lives:

Besides the fact that an especially high number of armed conflicts have broken out since 1945, new types of conflict have emerged (wars of national liberation, guerrilla warfare) and technological progress has resulted in the development of numerous high-performance weapons. In 1997, 25 major armed conflicts were waged in 24 places around the world. All the conflicts that broke out in 1997 were waged on the African continent, and Africa was the only region in which the number of conflicts increased. It was also the region with the largest share of high-intensity conflicts, i.e. those with more than 1,000 battle-related deaths in one year . The protagonists of international humanitarian law have undermined its set of rules, particularly; Echikwonye contends that the spirit of the international humanitarian law serves certain interest for the purpose of 
international politics. Echikwonye fails to recognize that violation of law does not mean the absence of its set of rules and spirits. Thus, international humanitarian law consists of a set of international rules, the purpose of which is to limit the effects of war on people and objects. These rules are laid down in international treaties that can be grouped into four categories:

(a) Treaties on the protection of victims of war,

(b) Treaties on the limitation and/or prohibition of different types of arms,

(c) Treaties on the protection of certain objects,

(d) Treaties governing international jurisdiction (repression of crimes).

All these treaties deal with specific humanitarian concerns in situations of armed conflict. While some of them apply almost exclusively to international armed conflicts, others apply to non-international armed conflicts. Therefore, arguing against the viability of the international humanitarian law to prevent war crimes is rather hypothetical and subjective notion, rather questioning States that failed to carry out legal obligation incumbent on them. These treaties are legal instrument to curtail international conflicts and internal conflicts in contemporary international system.

What does international humanitarian law protect and how?: International conflicts or internal conflicts? How does international humanitarian law deal with them?

In both internal and international armed conflicts, all the parties must comply with the rules of international humanitarian law, which nevertheless makes a distinction between the two. International armed conflicts are those in which two or more States have clashed using weapons and those in which people have risen in opposition to a colonial power, foreign occupation or racist crimes. They are subject to a broad range of rules, including those set forth in the four Geneva Conventions and Additional Protocol.

A more limited set of rules is applied in internal armed conflicts. They are contained in particular in Article 3 common to the four Geneva Convention and in Additional Protocol II, which has a narrower scope. Article 3 common to the Geneva Conventions states that, "in the case of armed conflict not of an international character occurring in the territory of one of the High Contracting Parties, each Party to the conflict shall be bound to apply, as a minimum, the following provisions:

(1) Persons taking no active part in the hostilities, including members of the armed forces who have laid down their arms and those places hors de combat by sickness, wounds, detention, or any other cause, shall in all circumstances be treated humanely, without any adverse distinction founded on race, colour, religion or faith, sex, birth or wealth, or any other similar criteria.

To this end, the following acts are and shall remain prohibited at any time and in any place whatsoever with respect to the abovementioned persons:

a. Violence to life and persons, in particular murder of all kinds, mutilation, cruel treatment and torture;

b. Taking of hostages;

c. Outrages upon personal dignity, in particular humiliating and degrading treatment;

d. The passing of sentences and the carrying out of executions without previous judgment pronounced by a regularly constituted court, affording all the judicial guarantees which are recognized as indispensable to civilized peoples.

(2) The wounded and sick shall be collected and cared for. 
An impartial humanitarian body, such as the International Committee of the Red Cross,, may offer its services to the Parties to the conflict. The Parties to the conflict should further endeavor to bring into force, by means of special agreements, all or part of other provisions of the present Convention. The application of the preceding provisions shall not affect the legal status of the Parties to the conflict". The question that what does international humanitarian law protect and how? Also provokes intellectual curiosity among scholars of geo-political divide. Scholars argued that the international humanitarian law does not have the legal capacity to protect all and sundry. The accusation is rooted round non-viability of its provisions. However, these scholars failed to recognize that international humanitarian law protects people and certain places and objects. It also prohibits the use of certain methods and means of warfare.

International humanitarian law protects people who are not or are no longer taking part in fighting, such as civilians, the wounded, the sick, and prisoners of war, the shipwrecked, and medical and religious staff. International humanitarian law also protects these people by obliging the parties to a conflict to provide them with material assistance and to treat them humanely at all times and without adverse distinction. The wounded and the sick must be collected and cared for; prisoners and detainees must receive adequate food and housing and benefit from judicial guarantee.

Meanwhile, the following are prohibited in all circumstances:

a. Violence to the life, health, or physical or mental well-being of persons, in particular murder, torture, corporal punishment and mutilation;

b. Outrages upon personal dignity, in particular humiliating or degrading treatment, rape, forced prostitution and any form of indecent behavior;

c. The taking of hostages;

d. Collective punishment;

\section{Threats to commit any of the above acts}

Moreover, any person charged with a criminal act in connection with an armed conflict must have a fair and regular trial and may be found guilty and sentenced only as an outcome of such a trial. The protagonists did not admit that international humanitarian law ensures fundamental guarantees of alleged offenders. The fundamental guarantees of international humanitarian law are a set of rules setting forth the minimum treatment to which any individual in the power of a party to the conflict is entitled. These rules are listed in Protocol I additional to the Geneva Conventions and must be respected at all times and in all places by the States party to the Conventions. They constitute a sort of "Declaration of Human Rights" applicable in time of war and make it possible to remedy the shortcomings of the law at such a time. They are a kind of safety net and, therefore, supplement rather than contradict the provisions affording greater protection to certain categories of people.

There can be no derogation from these rules, even in cases where State security or military necessity would seem to require it. As a result, failure to meet the fundamental guarantees represents, in most cases, a grave breach of international humanitarian law or, in other words, a war crime, and must be punished accordingly. The basic fights of individuals in non-international armed conflicts are not fundamentally different from those that are granted in international conflicts. Article 3 common to the four 1949 Geneva Conventions, supplemented and reinforced by Article 4 of Protocol II of 1977, 
also requires that individuals be treated humanely and prohibits at all times and in all places violence against the lives, health and well-being of people. Additional Protocol I of 1977 stipulates that "persons who are in the Power of a Party to the conflict shall be treated humanely in all circumstances", without any adverse distinction based on race, colour, sex, language, religion or belief, political opinion, etc. The law equally protects certain places and objects. Certain places and objects, such as hospitals and ambulances, are also protected and must not be attacked. International humanitarian law defines a number of clearly recognised emblems and signs-in particular the Red Cross and Red Crescent emblems which can be used to identify protected people and places. Even civilian population protected under international humanitarian law. In the additional Protocol I of 1977:

a. A distinction must be made between combatants and civilians in the conduct of hostilities. Civilians shall not be made the primary target of military operations or the incidental victims of the fighting.

b. The parties to a conflict must distinguish not only between the civilian also between civilian population and the combatants, but also between civilian property and military objects; this means that not only arc civilians as such protected, but also the goods needed for their survival or subsistence (foodstuffs, livestock, drinking water supplies, etc.).

c. Attacks and threats, the main purpose of which is to spread terror among the civilian population are formally prohibited,

d. Attacks whose effects cannot be limited to a specific military target or target are prohibited (massive at such which are not aimed bombardment, carpet-bombing). e. Civilians may in no circumstances be used to render certain points, areas or military' objects immune from attack.

f. Any act of hostility directed against historic monuments, works of art or places of worship, and the use of such objects in support of the military effort are strictly prohibited.

g. It is prohibited to destroy works containing dangerous forces (hydroelectric dams, dykes and nuclear power stations) which, if suddenly released, could take a high toll among the civilian population. By the same token, the parties to a conflict must take care not to place military objects near such works.

h. Special zones can be set up which are absolutely immune from attack. Hospital and safety zones and localities can be designated in time of peace to house certain categories of protected persons. Demilitarised zones can also be designated in time of peace; they may be neither attacked nor defended using military force.

The law even provided the means of protection. International humanitarian law prohibits methods and means of warfare:

i. That target people who are not taking part in the fighting. Methods and means of warfare that do not, for example, distinguish become combatants and protected persons, such as carpet bombing, are therefore prohibited.

ii. that cause superfluous injury. For example, humanitarian law prohibits the use of weapons whose effect would be excessive in relation to the military advantage anticipated, such as exploding bullets whose aim is to cause untreatable wounds.

iii. that cause lasting damage to the environment. The use of biological and 
chemical weapons and anti-personnel landmines is therefore prohibited.

In any armed conflict, the rights of the Parties to the conflict to choose methods or means of warfare are not unlimited. It is, therefore, prohibited to use :

a. Arms that do not discriminate between military and non-military targets, between combatants and protected persons (the recent treaty banning antipersonnel landmines is a good example);

b. Weapons, projectiles and other materials of a nature to cause superfluous injury to enemy fighters, i.e. that cause suffering that could be avoided if the objective sought were attained by causing a lesser degree of suffering;

c. Light and inflammable projectiles, bullets that spread or explode within the body (dumdum bullets), poison and poisonous weapons; weapons the primary effect of which is to injure by fragments which in the human body escape detection by $\mathrm{X}$ rays; booby-traps and incendiary weapons; methods or means of warfare which are intended, or may be expected, to cause widespread, long-term and severe damage to the natural environment.

The Missing Link

The paper has established how the international humanitarian law deals with international conflicts and internal conflict and what or/and who the law protects and how. The argument against the viability of the law is unfolded. The international humanitarian law is law in true sense of it. The provisions are viable and conceive to prevent war crimes. Its enforcement and enforceability should rather be the angle of argument among scholars but not provisions and the spirit of the law. To this end, the judicial organ of the international humanitarian law, the International Criminal Court (ICC) is empowered by virtue of the
Rome Statute to adjudicate cases related to international humanitarian law. Justice and politics have been the basis of its criticism. Critics of the ICC point out that both Sudan and Libya were referred to the Court by the UN Security Council, where three of five vetowielding countries (China, Russia and the United States) are not even members of the Court. While the Security Council was quick to have leaders of the two countries indicted, the critics have observed that efforts to refer countries like Syria have so far been thwarted by some of these countries. Even steadfast supporter of the Court, such as former UN Secretary-General Kofi Annan, agrees with some of the criticisms. He acknowledged several weaknesses of the Court . Most egregiously, only two of the five permanent members of the UN Security Council, the UK and France are signatories to the Rome Statute (and therefore members of the ICC), opening the Court up to accusations of double standards. Annan strongly advocates for the continent to stay engaged with the Court, saying, as ICC remains the continent's most credible Court of last resort for the most serious crimes.

These views are espoused by a majority of civil society organizations in Africa, doubtful of their own governments' abilities to prosecute serious crimes, even as African Union members push for the establishment of an African Court to try international crimes. To many observers, however, reforms may be just what aggrieved countries have been calling for all along. As early as 2013, Kenya asked for sitting presidents not to be indicted, while South Africa pressed for their immunity against prosecution to be respected. In the aftermath of its failure to arrest the Sudanese president, the South African government 
indicated that the main problem with the ICC is the obligation to arrest heads of state.

Even in March 2017, as Pretoria revoked its notice of withdrawal, a group of South African former constitutional judges were lobbying parliament against withdrawing from the ICC. Justice Zak Yacoob, one of the former judges, framed the issue at the time: In joining the ICC, South Africa made the choice of saying some human rights violations are so gross, so bad, so punishable, that no leader, even if he or she was a state leader at the time, should be able to get away with it. The ICC judges allegedly said, The ICC works within an imperfect framework. However, leading nations like South Africa and its parliamentarians should spearhead initiatives to improve the court. This is something that can only be done from within the system. Based on the forgoing analysis it is evidently clear that the provisions of the international humanitarian law are viable and coercive enough to deal with international conflicts and internal conflict and protect the legal personalities . Its enforcement and enforceability do not make the law ineffective.

\section{CONCLUSION}

The paper has established that the traditional Geneva Convention brought into being the newly created International Committee of the Red Cross in 1864, which became the source of the Geneva Convention now universally accepted as the International Humanitarian Law. The original Convention gave the impetus to the Red Cross movement throughout the world, and inspired the development in international law towards increasing regulation and, eventually, the restriction and final prohibition of war. While the second Geneva Convention of 1868 was on maritime, the third Convention of 1929 made the civilized world to finally accept the principle that the prisoner of war is not a criminal, but merely an enemy no longer able to bear arms, who should be liberated at the close of hostilities, and be respected and humanely treated while in captivity.

Inspite of the criticism against the operation of the ICC, seeing that, while seeking means to preserve peace and prevent armed conflicts between nations, it is likewise necessary to bear in mind the case where the appeal to arms has brought about by events which care was unable to avert. Animated by the desire to serve, even in this extreme case, the interests of humanity and ever progressive needs of civilization; thinking it important, with this object, to reverse the general laws and customs of war, either with a view of defining them with greater precision or to confining them within such limits as would mitigate them as far as possible. This is the angle that this paper stands differently from the critics of the international humanitarian law and its judicial organ, the ICC. Therefore, international humanitarian law is law and the operations of its judicial organ should not be used the basis to discard it relevance to prevent armed conflicts.

\section{REFERENCES}

1. International Committee of the Red Cross. Respect for International Humanitarian Law.( Handbook for Parliamentarians No.1999)

2. S.J,Goldstein, International Relations; Fouthe Edition(Priscilla Mcgreehn,2001); K.W. Charles, World Politics: Trends and Transformation, eleventh edition(Thomson Wadsworth,2007); M.A, Karen, Essentials of International Relations, (WW North and Company,2004)

3. J,T.Rourke, Taking Side, Clashing Views on Controversial Isuues in World Politics 
(McGranoHills/Dushkin,2005); C. Brown, understanding international Relations (New York Palgrave,2001)

4. M.A., Margesson, International Criminal Court in Africa: Status and Policy Issues (Congressional Research Service,Report for Congress,RL34665,2011 ), M., Kowalski, The international Criminal Court: Reflections for a Stress Test on its foundations (JANUS,NET E-Journal of international relations, 1 (2autumn))

5. Ibid See Echikwonye...

6. International Committee of the Red Cross. Respect for International Humanitarian Law.( Handbook for Parliamentarians No.1999)

7. International Committee of the Red Cross. Understanding the Humanitarian law:Basic Rules of the Geneva Conventions and their additional Protocols (ICEC,1983)

8. See Chapter VII of the United Nations Charter

9. Ibid

10. International Committee of the Red Cross. Respect for International Humanitarian Law.( Handbook for Parliamentarians No.1999)

11. A.B. Echekwonye. General Principles of international Law. (Unpublished lecture note, Benue State University Makurdi, 2019)

12. See Geneva Conventions and Additional Protocol I

13. See S.J,Goldstein, International Relations; Fourth Edition(Priscilla Mcgreehn,2001); K.W. Charles, World Politics: Trends and Transformation, eleventh edition(Thomson Wadsworth,2007); M.A, Karen, Essentials of International Relations, (WW North and Company,2004) ; J,T.Rourke, Taking Side, Clashing Views on Controversial Isuues in World Politics (McGrano
Hills/Dushkin,2005); C. Brown, understanding international Relations (New York Palgrave,2001); M.A., Margesson, International Criminal Court in Africa: Status and Policy Issues (Congressional Research Service, Report for Congress,RL34665,2011 ), M., Kowalski, The international Criminal Court: Reflections for a Stress Test on its foundations (JANUS,NET E-Journal of international relations,1(2autumn)) These rules are listed in Protocol I additional to the Geneva Conventions and must be respected at all times and in all places by the States party to the Conventions.

14. (see Repressing violations of international humanitarian law).

15. Article 3 common to the four 1949 Geneva Conventions (see page 13), supplemented and reinforced by Article 4 of Protocol II of 1977,

16. Additional Protocol I of 1977 stipulates that "persons who are in the Power of a Party to the conflict shall be treated humanely in all circumstances"

17. ibid

18. International Committee of the Red Cross. The Geneva Conventions of August 12,149 (ICRS, Geneva, 1991) 